\title{
Supporting Information: \\ Formylation Domain: An Essential Modifying Enzyme for the Nonribosomal Biosynthesis of Linear Gramicidin
}

\author{
Georg Schoenafinger, Nadine Schracke ${ }^{1}$, Uwe Linne and Mohamed A. Marahiel \\ Fachbereich Chemie/Biochemie, Philipps-Universität Marburg, Hans-Meerwein-Strasse, D-35032 Marburg, Germany; \\ RECEIVED DATE (automatically inserted by publisher); *E-mail: marahiel@chemie.uni-marburg
}

\section{Materials and Methods}

Strains, Culture Media, and General Methods. E. coli strains were grown in LB medium, supplemented with $50 \mu \mathrm{g} / \mathrm{mL}$ kanamycin (kan), 100 $\mu \mathrm{g} / \mathrm{mL}$ ampicillin (amp) or $34 \mu \mathrm{g} / \mathrm{mL}$ chloramphenicol (cm) (final concentration) depending on the plasmids and strains used (E. coli BL21 (DE3) pQE60-sfp: amp; E. coli BL21 CodonPlus DE3 pET24b+-folD: kan and cm, E. coli BL21 (DE3) pBAD202-fat and pBAD202-fatcat: kan). Standard procedures were applied for all DNA techniques ${ }^{1}$. Oligonucleotides were purchased from Operon Biotechnologies GmbH (Cologne, Germany). Sequence identity of all plasmids was confirmed by DNA sequencing carried out by GATC Biotech (Konstanz, Germany).

Construction of Expression Plasmids. The pBAD Directional TOPO Expression Kit from Invitrogen (Paiseley, UK) was used to generate the desired pBAD202-TOPO expression plasmids. Cloning and preparation of the plasmids was performed in E. coli TOP10 (Invitrogen). Genes of interest (Figure SI1) were PCR-amplified from chromosomal DNA of Bacillus brevis ATCC 8185. Primers used for the construction of pBAD202fat $\left[\mathrm{F}-\mathrm{A}_{1}-\mathrm{PCP}\right]$ are as follows: 5'-CAC CGT GAG AAT ACT ATT CCT AAC AAC-3', and 5'-TTG CTC CGT AAG CAG ACG-3'. For pBAD202-fatcat [F-A 1 -PCP-C-A ${ }_{2}$-PCP], 5'-CAC CGT GAG AAT ACT ATT CCT AAC AAC-3', and 5'-GAA TTC GGA CGT GAC GAA TGG GGC-3' were used. pET24b+-folD carries the folD-gene of Methanosarcina barkeri and was a generous gift from Dr. Bärbel Buchenau and Prof. Dr. R. Thauer, MPI Marburg ${ }^{2}$. FolD and Sfp were overproduced and purified from E. coli BL21 CodonPlus DE3 pET24b+-folD and E. coli BL21 DE3 pQE60-sfp, respectively, as described before ${ }^{2,3}$.

Production and Purification of Recombinant apo-Enzymes. All expression plasmids were used to transform E. coli BL21. The corresponding strains were grown in $6 \times 300 \mathrm{~mL}$ medium to an $\mathrm{OD}_{600}$ of 0.8 at $30{ }^{\circ} \mathrm{C}$. Expression was induced by addition of $0.08 \%$ (w/v) arabinose and growth continued for $14 \mathrm{~h}$ at $19^{\circ} \mathrm{C}$. Harvested cells were resuspended in $20 \mathrm{~mL}$ buffer HEPES A (50 mM HEPES, $300 \mathrm{mM} \mathrm{NaCl}$, pH 7.0) and lysed with a French pressure cell. Each lysate was clarified by centrifugation, and the supernatant was loaded onto a column containing $1.0 \mathrm{~mL}$ Superflow NiNTA purchased from Qiagen (Hilden, Germany). The column was washed successively with $10 \mathrm{~mL}$ buffer HEPES A containing $0 \%, 10 \%, 25 \%$, and $35 \%(\mathrm{v} / \mathrm{v})$ of buffer HEPES B (50 mM HEPES, $300 \mathrm{mM} \mathrm{NaCl}, 250 \mathrm{mM}$ imidazole, $\mathrm{pH}$ 7.0). The hexahistidine-tagged protein was eluted with $100 \%$ buffer HEPES B and dialysed against $1 \mathrm{~L}$ assay buffer $(50 \mathrm{mM}$ HEPES, $100 \mathrm{mM} \mathrm{NaCl}, \mathrm{pH} 7.0)$ three times, supplemented with $1 \mathrm{mM}$ DTT (final concentration) in the first two dialysis steps. Purity of the proteins was $>95 \%$ as judged by SDS-PAGE analysis ${ }^{4}$.

$$
\text { a) }
$$

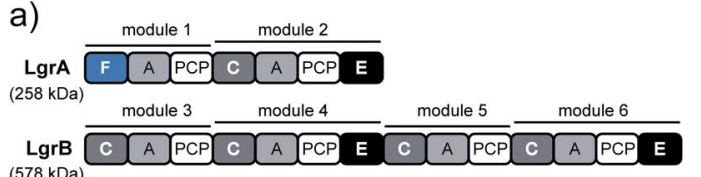

$(578 \mathrm{kDa}) \underbrace{}_{\text {module } 7} \underbrace{}_{\text {module } 8} 9 \underbrace{}_{\text {module } 10}$

\begin{tabular}{|c|c|c|c|c|c|}
\hline & & & & 71100 & \\
\hline $\operatorname{grC}$ & $\bar{c}$ & $\bar{A} / \mathrm{PC}$ & $\bar{c}$ & $\bar{A}$ & \\
\hline
\end{tabular}

(866 kDa) module 13 module $14 \quad$ module $15-$ module 16

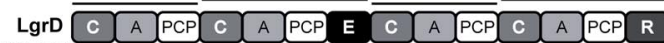

LgrE $R$ b)

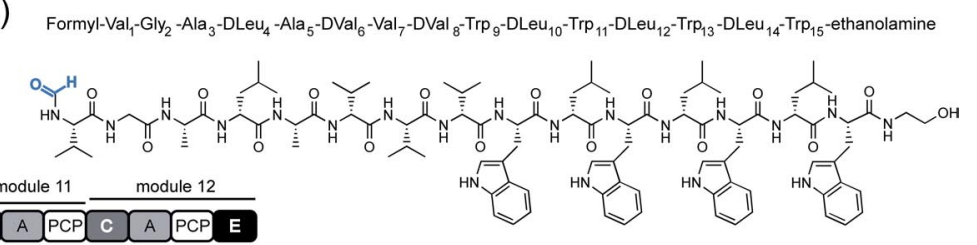

linear gramicidin $\mathbf{A}_{(\text {Val1) }}$ $(567 \mathrm{kDa})$

$(76 \mathrm{kDa})$

Figure SI1: Linear gramicidin biosynthesis and structure a) The nonribosomal peptide synthetases (LgrA-E) are responsible for the biosynthesis of linear gramicidins in B. brevis ATCC 8185. LgrA consists of two modules which comprise a total of seven catalytic domains. At the N-terminus, the postulated $\mathrm{F}$ domain is located, shown in blue. b) Chemical structure of linear gramicidin A. The natural product gramicidin is known to consist of various isoforms. Gramicidins A, B and C differ at position 11 (Trp, Phe or Tyr, respectively) and gramicidin D is the natural mixture of these (80\%, $5 \%$ and $15 \%$, respectively ${ }^{5}$.

\footnotetext{
${ }^{1}$ present address: Biozentrum der Universität Basel, Klingelbergstrasse 50-70, CH-4056 Basel, Switzerland
} 


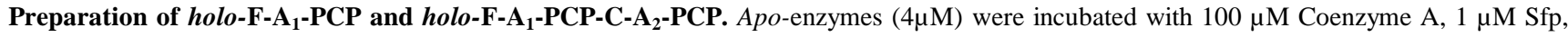
and $10 \mathrm{mM} \mathrm{MgCl}_{2}$ for $30 \mathrm{~min}$ at $25^{\circ} \mathrm{C}$ directly prior to subsequent assays without intermediate purification.

Preparation of $\mathbf{N}^{\mathbf{1 0}} \mathbf{f H}_{4} \mathbf{F} .500 \mu \mathrm{M} \mathrm{H}_{4} \mathrm{~F}, 8 \mathrm{mM} \mathrm{NAD}^{+}$, and $2 \mathrm{mM} \mathrm{HCHO}$ were dissolved in potassium phosphate buffer $\left(120 \mathrm{mM} \mathrm{K}_{3} \mathrm{PO}_{4}, 50\right.$ $\mathrm{mM} \beta$-mercaptoethanol, $\mathrm{pH} 6.0$ at $25{ }^{\circ} \mathrm{C}$ (Fig. SI2). $4 \mu \mathrm{M}$ FolD was added and the reaction progress was monitored by UV-spectroscopy at $340 \mathrm{~nm}^{2}$.

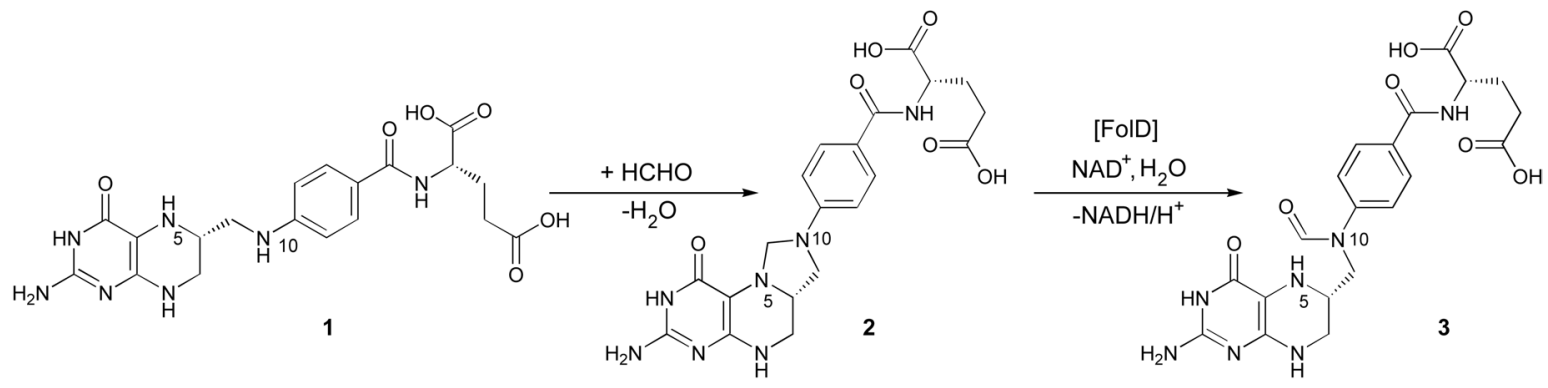

Figure SI2: Chemoenzymatic synthesis of $\mathrm{N}^{10}-\mathrm{fH}_{4} \mathrm{~F}$. Tetrahydrofolate (1) and formaldehyde condensate in aqueous solution, giving rise to 5',10'-methenyltetrahydrofolate (2) which is $\mathrm{NAD}^{+}$-dependently oxidized by FolD, regioselectively forming $\mathrm{N}^{10}$-formyl-tetrahydrofolate $(\mathbf{3})^{2}$.

Formylation Assays and Sample Preparation. Holo-enzymes $(4 \mu \mathrm{M})$ generated in situ (see above) were incubated with $100 \mu \mathrm{M}$ ATP, $100 \mu \mathrm{M}$ amino acid (valine, isoleucine or leucine), and $100 \mu \mathrm{M}$ of either $\mathrm{N}^{10}-\mathrm{fH}_{4} \mathrm{~F}$ prepared in situ as described above or $\mathrm{N}^{5}-\mathrm{fH}_{4} \mathrm{~F}$, respectively, in assay buffer (50 mM HEPES, $100 \mathrm{mM} \mathrm{NaCl}, \mathrm{pH}$ 7.0). Samples with a total volume of $200 \mu \mathrm{L}$ were kept at $25^{\circ} \mathrm{C}$ and incubated for $2 \mathrm{~h}$. Reactions were stopped and the proteins were precipitated by the addition of $1 \mathrm{~mL} 10 \%(\mathrm{w} / \mathrm{v})$ TCA. Samples were centrifuged at $4{ }^{\circ} \mathrm{C}$ and the pellet was washed three times with $500 \mu \mathrm{L} \mathrm{Et}_{2} \mathrm{O}: \mathrm{EtOH}(3: 1(\mathrm{v} / \mathrm{v}))$. Solvents were evaporated at $37^{\circ} \mathrm{C}$. Thioester cleavage was performed by adding $100 \mu \mathrm{L} \mathrm{KOH}(0.1$ M) to the dry pellets and incubating at $70{ }^{\circ} \mathrm{C}$ for $15 \mathrm{~min} .1 \mathrm{~mL} \mathrm{MeOH}$ was added and samples were kept at $-20{ }^{\circ} \mathrm{C}$ for $14 \mathrm{~h}$. Precipitated $\mathrm{KOH}$ was removed by centrifugation and the supernatants were dried by evaporation at $45{ }^{\circ} \mathrm{C}$ and $10 \mathrm{mbar}$ in a speed-vac system. The resulting pellets were dissolved in $30 \mu \mathrm{L} 95 \%$ acetonitrile (aq) containing $2 \mathrm{mM} \mathrm{NEt}_{3}$. For the time dependent formylation assays, identical procedures were used and samples were taken after $0,1,4,10$, and 100 minutes and immediately quenched by adding them to $1 \mathrm{~mL} 10 \%$ (w/v) TCA. The maximum yield of formylvaline was identical for both cofactors used, however with $\mathrm{N}^{10}-\mathrm{fH}_{4} \mathrm{~F}$ half the maximum yield was reached after only 19 seconds, whereas $\mathrm{N}^{5}$ $\mathrm{fH}_{4} \mathrm{~F}$ led to a 18 fold slower product formation ratio (330 seconds).

ATP/PP $\mathbf{P}_{\mathrm{i}}$-Exchange Assays. In order to give experimental proof for the catalytic activity of the $\mathrm{F}$ domain, first the substrate activation of the recombinant protein $\mathrm{F}-\mathrm{A}_{1}-\mathrm{PCP}$ was assayed in vitro. As described previously, the A domain recognizes and activates valine, isoleucine and leucine ${ }^{6}$ However, the question remained whether the first A domain also accepts formylated valine in the first place. The specificity of the A domain of F$\mathrm{A}_{1}$-PCP was therefore elucidated by $\mathrm{ATP} / \mathrm{PP}_{\mathrm{i}}$-exchange reactions using valine, formyl-valine, isoleucine and leucine, respectively (Fig. SI3). The results clearly indicate that valine is the dominant substrate with a turnover defined as $100 \%$, whereas side specificities towards isoleucine and leucine lead to relative activation ratios of $31.7 \%$ and $6.3 \%$, respectively. ATP/PP $\mathrm{P}_{\mathrm{i}}$-exchange triggered by the presence of formyl-valine yielded less than $0.1 \%$ of valine's turnover, clearly demonstrating that it is not a substrate for the A domain.

$50 \mu \mathrm{L}$ reaction mixture $\mathrm{I}$, containing $100 \mathrm{nM} \mathrm{F}-\mathrm{A}_{1}-\mathrm{PCP}$, and $1 \mathrm{mM}$ amino acid (valine, formyl-valine, isoleucine, or leucine), in assay buffer (50 $\mathrm{mM}$ HEPES, $100 \mathrm{mM} \mathrm{NaCl}, 10 \mathrm{mM} \mathrm{MgCl} 2, \mathrm{pH} 7.0$ ) was added to $50 \mu \mathrm{L}$ reaction mixture II, containing $10 \mathrm{mM} \mathrm{PP}$, $100 \mathrm{mM} \mathrm{ATP}$, and $5500 \mathrm{~Bq}$ ${ }^{32} \mathrm{P}$-radiolabeled $\mathrm{PP}_{\mathrm{i}}$ in assay buffer. Samples were incubated for $10 \mathrm{~min}$ at $37{ }^{\circ} \mathrm{C}$. Work-up and detection was carried out as described previously ${ }^{7}$.

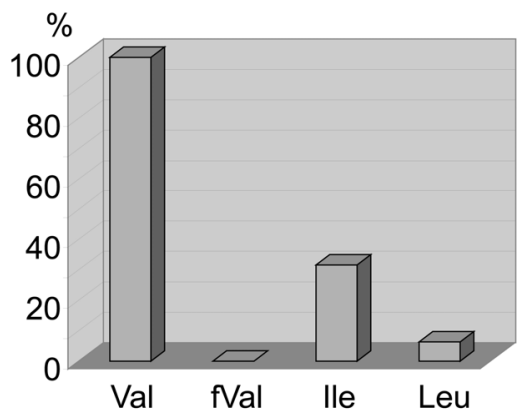

Figure SI3: Adenylation domain specificity. The A domain of LgrA1 mainly activates valine but is known to exhibit side specificity towards isoleucine and leucine. Formyl-valine (fVal), however, is not recognized. 
Assay Product Detection. Assay samples were analyzed by HPLC-MS (Agilent) using a CC 125/2 Nucleosil 100-5 $\mathrm{NH}_{2}$ column (MachereyNagel). $30 \mu \mathrm{L}$ of each assay sample were applied using the following HPLC gradient at a flow rate of $0.3 \mathrm{~mL} / \mathrm{min}$ and a column temperature of 40 ${ }^{\circ} \mathrm{C}$ [solvent A: $\mathrm{H}_{2} \mathrm{O}, 2 \mathrm{mM} \mathrm{NEt}_{3}$; solvent B: Acetonitrile, $2 \mathrm{mM}$ ]: Loading at $95 \%$ solvent B, linear gradient from $95 \%$ to $20 \%$ solvent B within 30 min, linear gradient from $20 \%$ to $95 \%$ within 10 min. Products were identified by comparison of retention times with standards purchased from Bachem (Bubendorf, Switzerland) as well as online ESI-MS and ESI-SIM (single ion mode) MS analysis with an Agilent 1100 MSD (Figure SI4). The ionization efficiency of both formylated and unformylated product species was determined by mass calibration with external standards, and the corresponding SIM-mass signals were integrated for quantification of the products/educts.

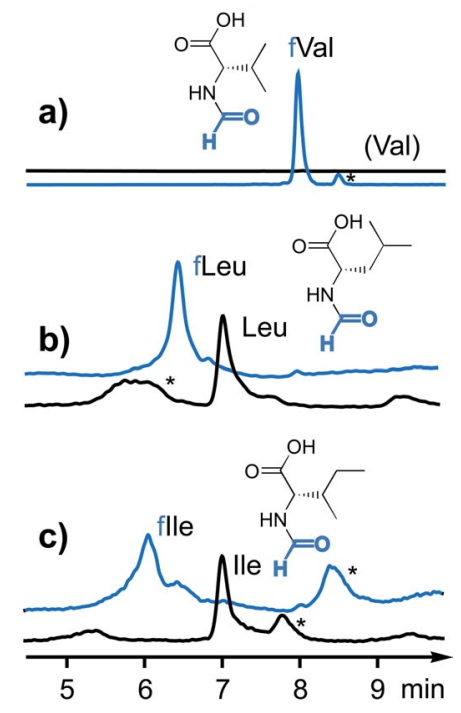

Figure S14: HPLC analysis of formylation assays using F- $\mathrm{A}_{1}$-PCP. Valine is completely converted to formyl-valine (a), whereas leucine (b) and isoleucine (c) are merely formylated with 5\% yield, as shown in these mass signals of the corresponding ions extracted. Signals marked with an asterisk are unidentified side products/impurities.

\section{References}

1. Sambrook, J.; Fritsch, E. F.; Maniatis, T., Molecular Cloning: A Laboratory Manual. Cold Spring Harbor Laboratory Press: Cold Spring Harbor, NY, 1989.

2. Buchenau, B.; Thauer, R. K. Arch Microbiol 2004, 182, (4), 313-25.

3. Reuter, K.; Mofid, M. R.; Marahiel, M. A.; Ficner, R. Embo J 1999, 18, (23), 6823-31.

4. Laemmli, U. K. Nature 1970, 227, 491-493.

5. Weinstein, S.; Wallace, B. A.; Morrow, J. S.; Veatch, W. R. J Mol Biol 1980, 143, (1), 1-19.

6. Kessler, N.; Schuhmann, H.; Morneweg, S.; Linne, U.; Marahiel, M. A. J Biol Chem 2004, 279, 7413-7419.

7. Mootz, H. D.; Marahiel, M. A. J Bacteriol 1997, 179, (21), 6843-50. 